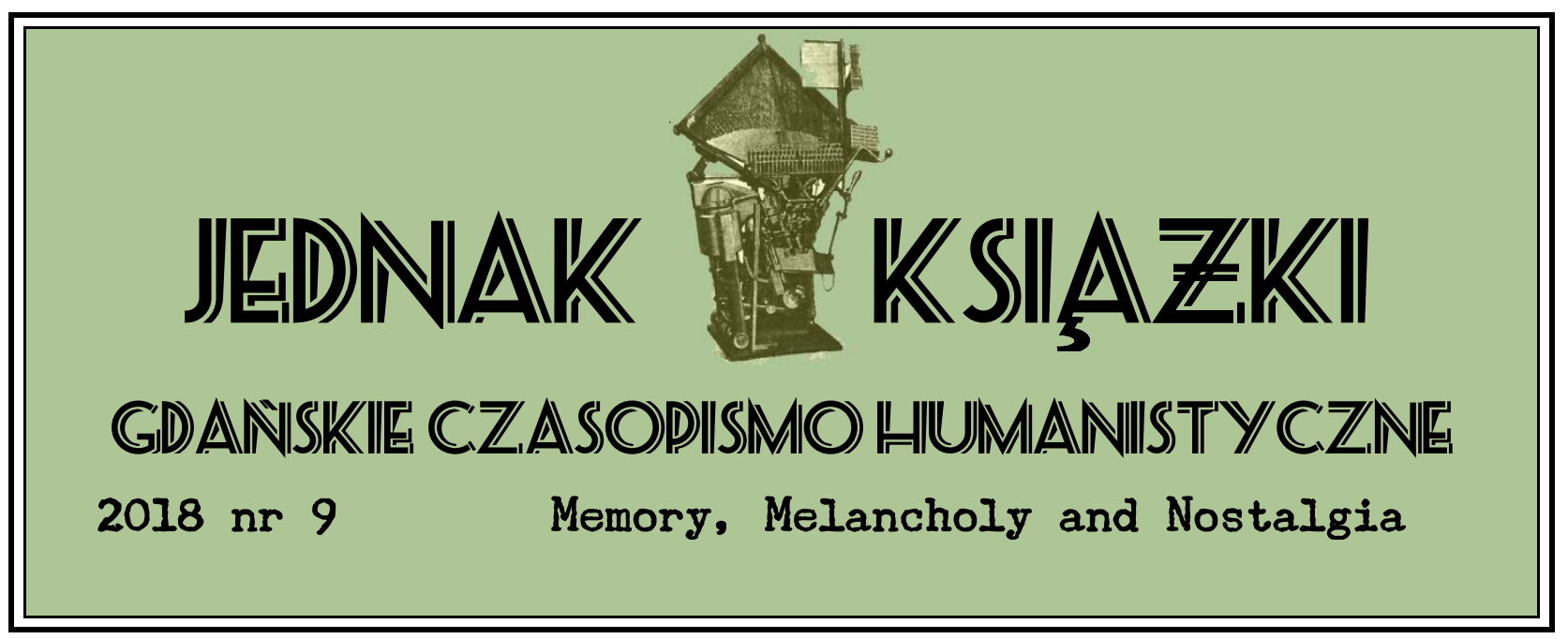

\title{
STUDIESS
}

\section{THE EXPERIENCE OF MELANCHOLY IN “DOMESTIC COMEDIES” BY HANOCH LEVIN}

\author{
MAGDALENA FIGZAŁ-JANIKOWSKA \\ University of Silesia in Katowice (Poland) \\ Department of Theatre and Drama
}

\section{Introduction}

mong Israeli contemporary playwrights and theatre directors Hanoch Levin is
undoubtedly one of the most renowned and prominent artists. His impressive legacy
includes 56 dramas, as well as poems, songs, satirical cabarets and books for children.

Before the author's death in 1999 Israeli theatres displayed 33 of his plays. He himself directed 22 of them. According to Freddie Rokem "a whole generation of Israeli theatregoers has grown up on Levin's performances, with of their paradoxical complexities" (Rokem 2003). On the one hand he was a radical political critic, on the other hand his dramas explored a variety of universal existential issues. Levin has received huge acknowledgement, but he has also been fiercely 
criticised. He was assailed by critics due to both his extremely left wing orientation and the use of earthy and vulgar language in his dramas.

Nevertheless, the phenomenon of Hanoch Levin has quickly spread to other countries. His dramas have been translated into more than a dozen languages and have been presented on many European and American stages. As an author he also became very popular in Poland - his dramas have been staged by numerous Polish theatre directors, including Krzysztof Warlikowski, Iwona Kempa, Jan Englert, Agnieszka Olsten and Małgorzata Bogajewska.

Dramaturgy of Hanoch Levin is entrenched in Jewish tradition and literature, however Israeli theatrologist Shimon Levy claims that it should not be the main perspective when interpreting his texts (Levy 2003). He writes that in Levin's plays the Israeli nature of the characters function only as a thin external layer. Comparing Levin's texts to Samuel Beckett's plays he underlines a universal purport of this dramaturgy. The topics which appear to be the most interesting for Levin are those which are fundamental for our existence: birth, love, suffering, loneliness, illness and death.

Nurit Yaari, the author of the article Life as a Lost Battle: The Theatre of Hanoch Levin, divides Levin's plays into three general categories:

1) Satirical cabarets: early political pieces which "are composed of a series of sketches interspersed with songs" (Yaari 1996: 153).

2) Domestic comedies: plays focused on familiar and neighbourly relationships, where "the dramatic space of these plays extends between the home, as the smallest unit, and the neighbourhood" (Yaari 1996: 157).

3) Spectacles of doom: plays which are based on ancient myths and biblical texts showing the anatomy of human condition determined by suffering and death.

Domestic comedies constitute the majority of Levin's dramatical works. Within this group Nurit Yaari identifies three subcategories of dramas with regard to their themes and protagonists: dramas of 'lonely hearts' (Ya'akobi and Leidental, The Rubber Merchants), 'family connections' (Shits, Winter Funeral, The labour of Life) and 'neighborhood' (Krum, Suitcase Packers). The characters of these plays usually represent the lower middle class - they are occupants of the same district or even the same street. Their monotonous life is presented in a cyclical way: from birth, throughout marriage and then disease, death and funeral. These moments inform us about the passage of time and indicate the changes in relationships between protagonists. 


\section{Melancholic Condition in Levin's Domestic Comedies}

The depicted world in Levin's domestic comedies consists of the same constant elements and is determined by the general outline of a locale (usually a house, room or street) and the presence of repetitive motives, situations, and the same types of dramatis personae. In fact, it can be argued that Levin uses limited character templates which he complements with variable details (such as name, age or profession) in particular dramas. The characters' identities are usually defined by their relations with others and their place in the family/social structure. They are always situated in a specific hierarchy, which portrays the bonds between them and illustrates their mutual dependence.

The existential frameworks of Levin's characters are defined in terms of fundamental bourgeois needs, in a well-structures hierarchical system: a man needs a woman, a woman needs a man. A mother wants to dandle a grandchild before she dies. A couple need a baby. A child is raised to fulfill his parents expectations by following in their precious footsteps, before, in, turn, finding himself a wife and repeating the process - ad infinitum (Yaari 1996: 160).

An inability to meet expectations; peer and public pressure; and one's awareness of his dependence on another person very often evoke frustration, dejection and 'eternal' suffering. Levin's dramatis personae still dream about a better life, about a different "here and now", but this is an all too distant reality. The author intentionally shows the contrast between their high spiritual aspirations and their struggles with daily and trivial reality. Agnieszka Olek finds that

the character's spirituality - their dreams, fears and feelings - is often covered with their corporeality (...) Body's problems, illnesses, weakness, defecation, urination are these elements which largely constitute their existence (Olek 2009: 18, translated from Polish - M. Figzał).

Levin describes this reality using a grotesque and absurd convention but nevertheless it is still a very sad and cruel view of life.

In Levin's domestic comedies we can find a gallery of the same type of people: lonely men and women who regularly miss their "last chance" for love; overprotective mothers, for whom their children's wedding is the main purpose of life; eternal dreamers who passively wait for a better future; and hypochondriacs constantly awaiting sickness and death. Common to all of them is a passive attitude towards the present. They usually participate in reality only in a physical way - their real feelings are located in the past and in memories or in idealistic visions of the future. This kind of condition which is based on withdrawal, resignation and permanent dissatisfaction with life is similar to melancholic way of experiencing reality. 
In Levin's domestic comedies melancholy can be considered in two contexts. Firstly, melancholy appears to be a general condition of the depicted world; secondly, it is deeply related to the individual experiences of the characters - their embodiment and their perception of the world. Commonly found in all these comedies is a melancholic figure - a depressed, detached subject, deprived of any possibility of symbolization. The condition of male and female characters in Levin's domestic comedies is usually determined by the longing for the past and the sadness of passive existence.

Though the idea of melancholy is very comprehensive and also polysemic, in this paper I will consider it in the context of psychoanalytical readings, especially Sigmund Freud's as well Julia Kristeva's works.

In the article Mourning and Melancholy Freud writes:

The distinguishing mental features of melancholia are a profoundly mental dejection, cessation of interest in the outside world, loss of the capacity to love, inhibition of all activity, and a lowering of the self-regarding feelings to a degree that finds utterance in self-reproaches and self-revilings, and culminates in a delusional expectation of punishment. (Freud 1957: 244).

In Black Sun: Depression and Melancholy Kristeva proposes a definition of melancholy which strictly corresponds with Freud's conclusions:

I shall call melancholia the institutional symptomatology of inhibition and asymbolia that becomes established now and then or chronically in a person, alternating more often than not with the so-called manic phase of exaltation (Kristeva 1989: 9).

Both definitions are concerned with the individual subject and its experiences. In the context of psychoanalytical theories melancholy always appears as a reaction for the loss of a loved object (Kristeva uses the word thing); where the subject is not able to accept the loss.

According to Freud the experience of melancholy is fairly similar to the experience of mourning. Nevertheless, the main difference between these two psychical conditions is the level of consciousness of the loss - in mourning the subject is always aware of the object-loss; and in melancholy the loss is often withdrawn form consciousness and is unknown to the subject. A melancholic suffers but simultaneously he is not able to state an adequate reason for his condition. Farther Freud indicates another important difference between melancholy and mourning:

The melancholic displays something else besides which is lacking in mourning - an extraordinary diminution of his self-regard, an impoverishment of his ego on a grand scale. In mourning it is the world which has become poor and empty; in melancholia it is the ego itself (Freud 1957: 246). 
In the context of psychoanalytical reading, melancholy means a disability of symbolic relation with the external world, which arises as a consequence of one's inability to accept the loss. Another perspective also considers melancholy as a general weakness of human existence. It refers to the state of spiritual exhaustion and emptiness. This view was presented several centuries ago in the comprehensive work of Robert Burton - The Anatomy and Melancholy from 1621 (Burton 2001).

In Hanoch Levin's dramas these two concepts of melancholy coexist together. Individual experiences and the mental states of the characters are usually portrayed against the collectivity, which includes relatives, friends, neighbours and random inhabitants of the town. In plays such as Krum and Suitcase Packers these people become both witnesses and participants in daily miseries. Levin situates his dramatis personae in a closed, stuffy and bereft of hope world, in which all days look the same - they are full of prosaic concerns and trivial conversations. Even especial moments such as weddings, funerals or new-born births become a cyclical part of the mundanity and are devoid of rightful celebration. Krum and Suitcase Packers is comprised of a few short scenes, which show the local community submerged in melancholic lethargy. This community is dominated by lonely men and women, unhappy spouses, widows and eternal hypochondrics. Their dreams and longings never materialise but instead remain in the sphere of imagination, becoming an idealized and unattainable desirable object.

This passive attitude to life and melancholic disposition have been directly expressed in one of Krum's monologues which took place in a cinema:

Projectionist, turn the lights off

So we do not need to see each other

And look each other in the face.

Show us something exciting

Something light and frothy

With beautiful happy well-dressed people (...)

We will sit in the dark and gaze at the light.

For two next hours we will drown our sorrows and indignities in it (...)

Oh movie, quivering strip of light 
Our hopes depend on you (...) (Levin 2009a: 206, translated from Polish - M. Figzał1

Krum and Suitcase Packers are thematically and structurally similar to each other - both dramas present the daily life of neighbours and both consist of a few independent grotesque scenes. The dramatis personae in these plays dream about a better life "somewhere else", but their fantasies are usually harshly contrasted with cruel reality. The title character of Krum says:

... and most of all I am waiting to miraculously get myself out from this shithole one day. Out of this town.

Into a white house with a garden, far from the buses and the smoke. With a beautiful sexy woman and two kids (Levin 2009a: 180)

Elhanan, a character from Suitcase Packers, also expresses his longing for a different and idealistic place to live, Switzerland. Every day he packs his suitcase with the intention of traveling, but sadly he makes it no further than the local bus stop.

ELHANAN: I will come and knock in the autumn evening, she will open the door looking incredibly happy, and then we will hug each other (...)

(he begins silently crying)

Give me at least one day without the longing. Only one day without the longing. I do not have any more strength. I am only human. I deserve a small parcel of peace and happiness (Levin 2009b: 490).

In these two dramas melancholy appears to express the mental condition of the characters and is depicted through constant dissatisfaction, the feeling of emptiness, relentless longing, malaise, the inability to act and a passive waiting for a change in fortunes. This melancholic disposition of Krum, Elhanan and other characters from these plays strongly influences their relations with the outside world. It can therefore be assumed that melancholy is strictly related to the way in which one perceives and experiences reality.

\section{Longing for the Past}

The melancholic mood in Levin's domestic comedies is often induced by the awareness of evanescence and uncertainty of life as well as by the sense of the irretrievable past. This is especially visible in two "plays with songs": The Rubber Merchants and Ya'akobi \& Leidental. Both plays comprise three middle-aged characters - two men and one woman. In The Rubber Merchant, Tsingerboy and Sprawl make amorous advances towards a chemist, Bella Berlo. Although all

1 All English translations of Hanoch Levin's dramas are based on Polish edition of his works (Levin Hanoch. 2009. Ja $i$ Ty $i$ następna wojna. Teatr życia i śmierci. Amiel Irit \& others, trans. Warszawa-Kraków.) and have been made by the author of this article. 
characters dream about true love and a peaceful life with another person they are unable to build a lasting relationship. The main obstacles are their weaknesses - egotism and materialism but also a fear of rejection. They all conclude that remaining in the sphere of own dreams is safer. When they meet each other again after twenty years they only despair and make no attempt to change their situation and fortunes:

TSINGERBOY: I am almost 65 years old and I am frightened. Since the moment of my birth till the day of my death there has been an open and dark chasm. What have I done with my best years? (Levin 2009c: 288)

The characters in Ya'akobi \& Leidental admittedly try to take their last chance but it does not make them happy - on the contrary, common life brings them more disenchantment. The two friends, Ya'akobi and Leidental, remain desolate and dejected. Their melancholic mood is expressed in the final song which they sing together:

You will not buy the piano

Oh my dear

You will not buy the piano

You will stay in the same dress

And in the evening, when the last sunbeams leave

You will have only a sad smile (Levin 2009d: 103)

The "sad smile" oxymoron and the phrase "the last sunbeams" evoke an association with the "black sun" metaphor from Gérard de Nerval's poem, which Kristeva used to describe melancholy:

The metaphor of the 'black Sun' for melancholy admirably evokes the blinding intensity of an affect eluding conscious elaboration. A powerful attraction, less than a sentiment, more intense than any word or idea: the narcissistic ambivalence of the melancholic affect alone finds, in order to represent itself, the image of death as the ultimate site of desire (Kristeva 1987: 10).

Leidental succumbs to the same "black sun" power and this is evidenced in his words:

And so time passes, spring, summer, autumn and winter, bloom and fall, and every season is so good to live in (...). But there you stand like a stone, doing nothing, plunged in sorrow, putting off everything till tomorrow, while time passes by and you feel your loss. And with a bitter sense of waste and regret, you stand and stare, and stare - and do nothing (Levin 2009d: 30).

When considering Freud's definition of melancholy which as previously mentioned is "profoundly mental dejection, cessation of interest in the outside world, loss of the capacity to 
love", Levin's domestic comedies present a classic type of melancholic. Among these distinguishing features of melancholy, Freud also mentions diminution and impoverishment of the ego:

The patient represents his ego to us as worthless, incapable of any achievement and morally despicable; he reproaches himself, vilifies himself and expects to be cast out and punished. He abases himself before everyone and commiserates with his own relatives for being connected with anyone so unworthy (Freud 1957: 246).

The characters in Levin's comedies very often blame themselves for their failures, whilst at the same time expressing a deep disapprobation of their ego. An example of this subjection are the words of Tachteech, one of the characters in Krum, who has been left by his beloved woman: "Living is no good... Especially for someone who doesn't deserve it". Subsequently in the dialogue with Krum - his purported rival - he abased himself:

TACHTEECH: It is me - Tachteech. I am standing here half the night and waiting while you are upstairs with Truda. I saw. First there was light, then you turn it off for a while, and then there was light again.

KRUM: What do you want?

TACHTEECH: I want to know who owns the woman I love. (...)

KRUM: Why do you humiliate yourself like that? You reportedly graduated from technical university.

TACHTEECH: I did not graduate from anything. I am only a technician. (...)

KRUM: You make me feel big. Get the fuck out of here.

TACHTEECH: Your wish is my command. You are the master. You have got Truda. And remember: even if you are so small I will be smaller (Levin 2009a: 186-187).

According to Freud, this tendency to self-deprecate is related to the loss of beloved object, which has been relocated into an interior space of the subject. "In this way - Freud states - an object-loss was transformed into an ego-loss and the conflict between the ego and the loved person into a cleavage between the critical activity of the ego and the ego as altered by identification" (Freud 1957: 249). Moreover, Kristeva claims that this disenchantment which is associated with a definite loss may awake the echoes of old traumas (Kristeva 1989: 4-5). 


\section{Conclusion: The Possible Source of Melancholic Disposition}

In Levin's dramas women are usually much stronger than men. Their perception of reality is more practical, therefore, the tendency to fall into a melancholic mood is much lower for them. Among various female characters in Levin's comedies an overprotective and apodictic mother holds a dominant position. Levin usually focusses on the relationship between mother and son, that can be treated both, realistically and symbolically. Here the father figure doesn't exist at all or appears only in the middle distance. The Woman-Mother is the one who plays a paramount role in the family hierarchy. The degradation of the Father or his absence has a destructive impact on the son and strongly influences the formation of the son's subjectivity.

In Levin's dramas the relationship between mother and son returns as a classic leitmotif. Treated in a symbolic way it may indicate the main source of the melancholy among male characters. To explain this connotation we should reconsider the main thesis of Black sun..., where melancholy appears to be a disability of the symbolic relation with the outside world. According to psychoanalytical theories, the subject needs to convert from the semiotic (what is connected to appetences, emotions and libido) towards the symbolic interpretation of the world. This is the main condition to establish subjectivity. The Mother embodies everything what is semiotic, meaning the son's relinquishment of the Mother is necessary to convert into a symbolic order and obtain subjective self-reliance. A melancholic's main problem is that he is unable to accept this interposition and the consequent loss. Relations between mother and son in Levin's comedies perfectly exemplify this type of psychoanalytical thesis. An ambivalent attitude towards the lost object can also be observed.

This difficult love full of detestation and mutual grievances is portrayed in Krum and Suitcase Packers. In both dramas the crucial moment to recognize the identity of the lost object is the real mother's death. Krum comments on this as follows:

Return to life, my dear. Reawaken my childhood belief in your invincible powers. (...) Get up, Mother. Come inside and make me lunch, because I will not accept it any other way. Never. Never. No, not yet. I am not ready for this kind of crying. No, there is still time for this kind of sorrow. I am not ready yet. Later (Levin 2009a: 240-241).

The consequence of the inability to accept the loss is incessant postponed mourning. In Suitcase Packers Elhanan is also not able to accept his significant loss:

We still have not explained anything to each other, what is there to explain. We have not considered any important topics of conversation. We have not said anything to each other yet. We need to talk mum, we still need to talk (Levin 2009b: 499). 
Both scenes are situated at the end of the dramas and provide the reader with an explanation of Krum and Elhanan's melancholic disposition. Both characters have experienced unattributable loss in the past and this has evoked feelings of emptiness and sense deprivation. Their mothers' deaths allow them to realise the identity of the lost object but this does not necessarily mean they need to accept the loss.

The depicted world in Levin's comedies is full of sadness, suffering and truculence, but simultaneously its absurd and grotesque character is presented. The melancholy appears to be a part of characters' daily lives, becoming a natural and immanent aspect of their existence. This melancholic mood influences both the way in which they perceive reality and how they experience it. 


\section{ACKNOWLEDGEMENTS}

All articles published in the issue are the revised texts based on lectures delivered at the $4^{\text {th }}$ International Interdisciplinary Memory Conference in Gdansk "Memory, Melancholy and Nostalgia" (17-18 Semptember, 2015).

SUMMARY

The Experience of Melancholy in "Domestic Comedies" by Hanoch Levin

The article attempts to depict the experience of melancholy in family dramas by an Israeli playwright Hanoch Levin. With regard to their themes Levin's domestic comedies can be divided into dramas of 'lonely hearts', 'family relationships', and 'neighborhood'. What is common to these three groups of dramas is the gallery of the same personae - melancholy men: depressed, detached subjects, deprived of any possibility of symbolization.

Firstly, melancholy appears to be a general condition of the depicted world; secondly, it is deeply related to the inner dramas of personae of the drama - their embodiment and their perception of the world. The condition of male and female characters in Levin's domestic comedies is determined by the longing for the past and the sadness of passive existence.

The basic purpose of the article is to provide an analysis of the selected issues in the context of psychoanalytical readings of melancholy, especially Sigmund Freud's as well Julia Kristeva's works. This perspective allows to elucidate the melancholic condition of dramatis personae, and also to describe some complicated relationships between them (especially the relation between mother-figure and the son).

\section{KEYWORDS}

Hanoch Levin; melancholy; Israeli drama; domestic comedy 


\section{BIBLIOGRAPHY}

Burton Robert. 2001. The Anatomy of Melancholy. New York: New York Review Books.

Freud Sigmund. 1957. Mourning and Melancholia, 243-258. In: Strachey James, ed. \& trans. The

Standard Edition of the Complete Psychological Works of Sigmund Freud. London: Hogarth Press.

Kristeva Julia. 1987. “On the Melancholic Imaginary”. New Formations (3): 5-18.

Kristeva Julia. 1989. Black Sun: Depression and Melancholia. Roudiez Leon S., trans. New York: Columbia University Press.

Levin Hanoch. 2009a. Krum. Poniedziałek Jacek, trans. In: Ja i Ty i następna wojna. Teatr życia i śmierci, 175-241. Warszawa: Agencja Dramatu i teatru „ADiT”. Kraków: Wydawnictwo Austeria.

Levin Hanoch. 2009b. Pakujemy manatki. Poniedziałek Jacek, trans. In: Ja i Ty i następna wojna. Teatr życia i śmierci, 443-502. Warszawa: Agencja Dramatu i teatru „ADiT”. Kraków: Wydawnictwo Austeria.

Levin Hanoch. 2009c. Sprzedawcy gumek. Olek Agnieszka, trans. In: Ja i Ty i następna wojna. Teatr życia i śmierci, 243-316. Warszawa: Agencja Dramatu i teatru „ADiT”. Kraków: Wydawnictwo Austeria.

Levin Hanoch. 2009d. Jakobi i Leidental. Sobelman Michał, trans. In: Ja i Ty i następna wojna. Teatr życia i śmierci, 55-103. Warszawa: Agencja Dramatu i teatru „ADiT”. Kraków: Wydawnictwo Austeria.

Levy Shimon. 2003. Daring to Compare: Samuel Beckett and Hanoch Levin, 61-68. In: Ben-Zvi Linda, ed. Drawing on Beckett: Portraits, Performances, and Cultural Contexts. Tel Aviv: Tel Aviv University.

Olek Agnieszka. 2009. Śmieszna baśń przez łzy - o spotkaniu z teatrem i dramatem Hanocha Levina, 4-48. In: Levin Hanoch. Ja i Ty i następna wojna. Teatr życia i śmierci. Warszawa: Agencja Dramatu i teatru „ADiT”. Kraków: Wydawnictwo Austeria.

Rokem Freddie. 2003, Introduction, IX-XXXIII. In: Levin Hanoch. The Labor of Life: Selected Plays. Harshav Barbara, trans. Stanford, California: Stanford University Press.

Yaari Nurit. 1996. Life as a Lost Battle: The Theater of Hanoch Levin, 151-171. In: Ben-Zvi Linda, ed. Theater in Israel. Michigan: The University of Michigan Press. 